\title{
A First Look at Harm Toward Animals by Bahamians in Childhood
}

\author{
William J. Fielding, Raymond A. Oenbring, Shane Brennen, \\ Marie C. Carroll, Nicolette Bethel, and Jessica Minnis \\ The College of The Bahamas ${ }^{1}$
}

\begin{abstract}
This paper reports on the first known study on childhood harm towards animals in The Bahamas. Using the Children and Animals Inventory (CAI), an Internet survey involving 1,558 respondents allowed childhood harm towards animals, to be investigated in the context of other violent behaviours in the child's home. The homes of children who did not harm animals were less violent than the homes of children who harmed animals. Consistent with other studies, males were more likely to harm animals than females; further, males were more likely than females to harm sentient animals. While the use of violence to train children was not associated with a higher CAI score, domestic violence and the presence of a gun in the home were associated with a higher CAI score. The implications of these findings as they relate to the treatment of living creatures are discussed.
\end{abstract}

\section{INTRODUCTION}

An ever-expanding body of knowledge supports the idea that the abuse of animals and people is linked (e.g., Ascione, 2008; Ascione \& Arkow, 1999; Lockwood \& Ascione, 1998; Petersen \& Farrington, 2007). The link can be thought of as a "pathway to future violence" either because violence towards animals "desensitized" the victimiser to aggression or by allowing "the floodgates restricting violence" to be opened (Arluke, 2007, p. 416). Gansler (2008) states:

Children exposed to these activities [animal cruelty and animal fighting] are at greater risk of being perpetrators or victims of crimes of violence. Animal abuse often occurs in the context of family violence and is frequently associated with ... possession of dangerous weapons, and other offenses (p. C2).

\footnotetext{
${ }^{1}$ W. J. Fielding, Director, Planning Unit : Raymond A. Oenbring, Assistant Professor School of English Studies; Shane Brennen, Assistant Professor, School of Socią' Sciences; Marie C. Carroll, Assistant Professor, School of Social Sciences; Nicolette Bethel, Assistant Professor, School of Social Sciences; Jessica Minnis, Assistant Professor, School of Social Sciences all at The College of The Bahamas, P.O. Box N-4912, Nassau, Bahamas.

Acknowledgments: The authors are grateful to the students at The College of The Bahamas in assisting with the data collection. The authors gratefully acknowledge Kevin Sherin and Mark Dadds for permission to use their questions and to Phil Arkow for reading an earlier draft of this paper. The final version of the paper benefited from the comments of the anonymous referees and Virginia Ballance.

E-mail: wfielding@cob.edu.bs

How to cite this article in APA 7th ed. style: Fielding, W. J., Oenbring, R. A., Brennen, S., Carroll, M. C., Bethel, N., \& Minnis, J. (2011). A first look at harm toward animals by Bahamians in childhood. The International Journal of Bahamian Studies, 17(2), 27-49.

https://doi,org/10.15362/ijbs.v17i2.134
} 
Thompson and Gullone (2008) have pointed to the fact that children can learn cruelty towards animals; therefore, their childhood experiences in this regard are important as such activities may persist beyond childhood. Animal abusers can apparently graduate from harming animals in their childhood to harming people in adulthood (Wright \& Hensley, 2003).

Tallichet and Hensley (2004) have reported that "animal cruelty is, at least in part, a learned behavior" (p. 45) and links between animal cruelty and violent acts toward humans in adulthood have been found (e.g., Merz-Perez \& Heide, 2003). Bevan and Higgins (2002) have also shown that the childhood home environment can play an important role in shaping the interpersonal behavior of males in adulthood. Flynn (1999) has shown that the treatment of children, particularly corporal punishment, can be correlated with childhood acts of cruelty towards animals. In Norway, Ellingsen, Zanella, Bjerkås, and Indrebø (2010) noted "early experiences in keeping pets as a child often help set a pattern for adult life" (p. 238). It should be noted that the associations above have not been observed by all researchers (e.g., Tallichet, Hensley, \& Singer, 2005), and that that the graduation theory, although longstanding (e.g., William Hogarth's prints The Four Stages of Cruelty, 1751), is not accepted by all researchers (e.g., McPhedran, 2009). While the triggers which may result in some children who harm animals later harming people are as yet unknown and subject to debate (Beirne, 2004), there seems sufficient evidence to suggest that it is important to learn about childhood interactions with animals and the animals which may be most at risk of harm.

To date, most of the research on childhood cruelty towards animals has occurred in North America, Australia and Europe, and while research is now expanding to other areas such as Malaysia (Mellor, Yeow, bt Mamat, \& bt Mohd Hapidzal, 2008) and Japan (Yamazaki, 2010), there is still a need to examine childhood harm towards animals in other communities.

Despite the expanding evidence which typically supports the idea of an association between harm of animals and harm of people, the research methods used remain problematical, as they often depend upon selfreporting and may not include all the issues which have an impact on the human or animal violence (Arluke, 2007; Ascione \& Shapiro, 2009). Patterson-Kane and Piper (2009) caution researchers about making too much of linkages as this may fail to indicate that multiple factors contribute to harmful behaviours. Such problems are not unique to this area of research but also apply to other related areas, such as childhood events and later behaviour (e.g., Maas, Herrenkohl, \& Sousa, 2008).

\section{Animals in The Bahamas}

While The Bahamas comprises hundreds of islands and cays, the majority of its residents (69.4\%) live on one island (New Providence, where the capital, Nassau, is situated). This results in a population per square kilometre of 1,018 in New Providence, but as low as one per square kilometre on other islands (Bahamas Department of Statistics, 2002). Therefore, the majority of human-animal interactions would be expected to occur in an urban setting. Although The Bahamas is surrounded by sea, relatively few persons $(1.7 \%)$ are employed in the agricultural, hunting, or fishing industries (Bahamas Department of Statistics, 2002). Therefore, it can be expected that most people will be exposed to domestic animals, and urban wildlife associated with a sub-tropical environment (e.g., birds, mosquitoes, cockroaches, termites, frogs, lizards and nonpoisonous snakes [Bahamas High Commission, 2009]) rather than farm animals 
or animals which might be hunted. Within homes, dogs are the most common pet (Fielding, 2008a) but they are also considered a nuisance and many are allowed to roam, which puts them at risk of harm (Fielding, 2008b). Although cats are less common than dogs, their level of care is similar and they too are allowed to roam (Fielding, 2009).

\section{Violence towards humans in The Bahamas}

The Bahamas appears to have a high level of violence, both in terms of domestic violence (McEwen, 2010) and homicides (Hanna, 2011). Increases in the number of homicides connected to domestic violence and increases in child abuse in recent years also suggest that children as well as adults are at risk of harm (Plumridge \& Fielding, 2009).

Spanking, or the use of violence to discipline Bahamian children, is common (Brennen, Fielding et al., 2010) and may be rooted in cultural (Knowles, 2000) and religious beliefs (Otterbein \& Otterbein, 1973). The implications of abuse of children and adults are well known, (e.g., Maas et al., 2008; Rivett \& Kelly, 2006). Within The Bahamas, Knowles (2000) has shown that male children who were abused were likely to be more aggressive and more likely to suffer from other problems than non-abused males. Burnett-Garraway (2001) has identified several predisposing risk factors of female victims of domestic violence which included "younger age, being single, low level of education, substance use, economic hardship and crowding in the home" (p. ii).

Violence towards animals in The Bahamas Many homes in New Providence keep pets (52.1\%, according to Fielding and Plumridge, 2005), and so this provides the opportunity for children to interact with animals, both in benign and/or antagonistic ways. Few studies have focused on harm towards pets or other animals in The Bahamas. However, in common with other countries, neglect appears to be the most common form of abuse of companion animals.

In The Bahamas, the most common acts towards dogs which students considered cruel were, in order of most agreement: general neglect, hitting with rocks, beating, or abuse (unspecified) and poisoning (Sawyer, 2002, reported in Fielding, Mather, \& Isaacs, 2005). Some dogs are used in (illegal) dog fighting, and it has been reported that dogs are subjected to violence which can lead to their being injured (Fielding, 2010a). While limited work has been done on what actions constitute cruelty, adult caregivers of dogs have a clear idea of abuse. This focuses on the provision of standard and enriched levels of care as well as the avoidance of physical harm to the dogs (Fielding, 2010b).

Dogs are hit as a means of discipline, and while intentional harm of dogs is not widespread (Fielding, 2010c), its presence is a concern. Both the Bahamian media and Internet sites report stories of neglect and intentional harm of animals, and officers of the Bahamas Humane Society have a long experience of animal cruelty, which typically affects dogs (Rolle, 2009). While local animal welfare groups are aware of the danger to society posed by people who harm animals (Aranha, 2009), this is not always appreciated by the wider public (Fielding \& Plumridge, 2010). Consequently, it appears that opportunities exist for children to mistreat either pets or other animals within an urban environment.

\section{Study purpose}

This study was designed to investigate childhood harm of animals by Bahamians. In particular it sought answers to the questions: (a) Do males and females exhibit similar levels of harm towards animals? (b) What types of animals are victims of harm? (c) Are there any links between childhood harm of animals and the domestic environment in which the children lived? In particular, do 
children who live in violent homes exhibit a similar level of harm towards animals as those who do not?

\section{METHODOLOGY}

Ascione and Shapiro (2009) list a range of survey instruments developed in recent years to assess animal cruelty. The survey questions in this study included those from the Children and Animals Inventory (CAI) originally published by Dadds et al. (2004), and listed in Dadds (2008). The inventory collects information on nine aspects of animal harm: (a) whether the respondents have ever harmed an animal on purpose; (b) the number of events causing harm to animals; (c) the types of animals harmed; (d) the period of time over which the respondent harmed animals; (e) the time since the last event of harm; (f) whether the harm was done in front of other people; and $(\mathrm{g})$ if so, in front of whom? The CAI also asks: (h) respondents' reaction to the harm at the time of the event; and, finally, (i) respondents' reaction to people harming animals.

The questions in the Dadds et al. (2004) survey were slightly modified after a pilot study with college students indicated that their wording was not clear in the Bahamian context. The pilot respondents indicated the need to explain the word animal. Therefore, the survey form indicated that except when otherwise specified the word animal in the questions referred to any living creature, dog, cat, snake, insects etc. The word child referred to the respondents' lives until the age of 18. (In The Bahamas, persons under the age of 18 are legally considered as children.) Given that many caregivers allow their cats and dogs to roam in The Bahamas, Dadds' single question on abuse of stray animals in the CAI was replaced by two: one which referred to stray cats and dogs, and another which referred to other stray animals. The answers from these two questions were, however, combined to obtain one score (the highest from the two questions) when calculating the CAI score. In calculating the CAI score, the open-ended questions were not included as many respondents did not answer these questions, and this would have reduced the number of scores available for analysis. However, these answers were used to gain insight into the quantitative data and were themselves subjected to a textual analysis, as suggested by Pagani, Robustelli and Ascione (2010).

In addition to classifying the answers of openended questions into themes, the methods of discourse analysis were applied strategically to respondents' open-ended answers, to further examine them. Following the now broadly-held contention in many areas of humanities and social science that language constructs conventional wisdom about the world, discourse analysis is a set of methods used by researchers to interrogate the reigning practices of language in a given area.

While discourse analysis is usually thought of as a decidedly qualitative and/or interpretative approach, some discourse analysts adopt more quantitatively-focused approaches. Many of these discourse analysts have advocated techniques for sorting through large amounts of data developed by corpus and computational linguists. One of these techniques uses computer software to search for $\mathrm{N}$-grams (that is, frequently repeated strings of words within a text or group of texts). In the study, N-grams were searched using the AntConc 3.2.1 software (Anthony, 2007). The current study follows a number of others in using the tools of corpus linguistics and discourse analysis to investigate different cultures' ideas about animals and their place in society (e.g., Durham \& Merskin, 2009; Hsieh, 2006; Swan \& McCarthy, 2003).

Questions were included to explore the demographics of the respondent: the presence of selected household behaviors, such as domestic violence as determined by the HITS 
screening tool (Sherin, Sinacore, Li, Zitter, \& Shakil, 1998), violence towards children and animals and the presence of a firearm in the home. These questions were included as Fielding and Plumridge (2010) identified a link between hitting pets as a means of discipline, and the intentional harm of pets in The Bahamas. A study from the United States by Azrael and Hemenway in 2000 showed that guns can be used to threaten other members of the household and so guns can be a component of domestic violence (Frattaroli, 2009). A summary of the questions included in the survey is given in Table 1.

Table 1

Summary of the questions included on the survey form

\begin{tabular}{l} 
Demographics of the respondent \\
Children and Animals Inventory questions \\
HITS questions \\
\hline As far as you are aware, was your mother or female \\
guardian ever hit by your father or by her boyfriend \\
(intimate partner)? \\
As a child were you ever hit as a form of discipline? \\
As far as you were aware, when you were a child, did \\
anyone in the household keep a firearm? \\
When you were a child: If cats and or dogs were kept by \\
the household did you see adults hit the animals? \\
Would you say that your childhood home was a loving \\
household? \\
If you are a parent, do you hit your children as a means of \\
discipline?
\end{tabular}

These questions were selected so that links, if any, between childhood harm of animals and aspects of the household environment could be identified. Therefore, the survey allowed some possible links between childhood harm towards animals to be studied in the context of other forms of household violence.

A SurveyMonkey ${ }^{\mathrm{TM}}$ link to the questionnaire was distributed via email to as many people as possible using a snow-ball technique. College social science students in five classes were asked to complete the survey form and to email the link to the survey to as many people as possible. They, in turn, were also asked to forward the link to their contacts. In some classes, instructors gave credit for student participation based upon the number of participants they recruited. Multiple answers per computer were permitted in order to allow students to participate using computers in the college's computer laboratories. The data were collected in the Fall Semester of 2009. The consent form was included in the survey form (agreeing to the question concerning consent was required to allow respondents to enter the survey) and the research project was carried out with the consent of the Office of Research, Graduate Programmes and International Relations of The College of The Bahamas.

It should be noted that a 2009 study using a random sample of school students, in primary and secondary public schools, indicated that over $63.7 \%$ of primary students and $71.2 \%$ of high school students had access to the Internet at home (Bahamas Ministry of Education \& The College of The Bahamas, 2009). In 2008 , it was estimated that $31.5 \%$ of the population of The Bahamas used the Internet (United Nations Statistics Division, 2009). Consequently, while Internet access is not universal, it is widespread and possibly increasing. A study from the United States has indicated that there, the use of Internetbased surveys may result is some biases, but that they may not necessarily be any more biased than other survey methods which rely on self-selected participants (Gosling, Vazire, Srivastava, \& John, 2004).

Little is known about the biases of using the Internet as a research tool in The Bahamas. The authors make no claim that the respondents in the study are representative of the wider community of The Bahamas, but this does not invalidate associations noted within the respondent group. Despite the limitations of the study the authors view the current study as an important addition to public discourse within The Bahamas and 
scholarly circles within and outside The Bahamas about the connections between violence towards animals and violence towards humans. The Bahamas is a small developing nation, and there remain few publicly-available, quantitatively-focused studies of Bahamian society. Accordingly, we see value in the presentation of raw data over academic theory-massaging.

In all, 2,211 responses were logged. However, not all the respondents agreed to participate (withheld consent to participate), some forms were scarcely completed and some appeared to be duplicates, as if the respondent was unsure if the first attempt at submitting the form had been successful. After cleaning the data, 1,881 responses remained.

Extensive demographic information was collected in the survey, making it possible to describe key characteristics of the respondent population and ensure that only respondents from the target population (that is, Bahamian citizens living in The Bahamas) were included in the analysis. These demographic data were used to exclude all those who were not Bahamian citizens living in The Bahamas. This then allowed us to focus our attention on 1,558 respondents who were Bahamians living in the cultural and physical environment of The Bahamas.

Respondents had the option to leave questions unanswered, so 1,558 represents the maximum number of respondents to a question. Percentages are based upon the number of answers to a particular question. The internal consistency of the HITS index as measured by Cronbach's alpha was 0.77 and that for the CAI 0.68, which therefore demonstrate a satisfactory level of consistency (Bland \& Altman, 1997).

\section{RESULTS}

Respondents' background

The majority of respondents-90.1\% (of 1,558) — lived on New Providence, 5.5\% lived in Grand Bahama and $4.3 \%$ on other Bahamian islands. The modal age group was $18-20$ years $(47.1 \%$ of 1,433 of whom $70.1 \%$ were aged under 26 years) and $64.7 \%$ (of $1,435)$ were female. About half of the respondents $(51.0 \%$ of 1,435$)$ were members of the general public and the remainder were either college students $(47.8 \%)$ or college employees (1.2\%).

Guns were reported in $26.0 \%$ (of 1,308 homes) and domestic violence occurred in $39.8 \%$ of 1,383 homes. Of 1,400 respondents, $22.7 \%$ indicated that their mother was definitely or probably hit by her intimate partner. Only $7.3 \%$ of 1,434 respondents had not been subjected to corporal punishment as a child, and $4.4 \%$ thought that they had been abused as a result of this corporal punishment; $68.3 \%$ of respondents had been hit sometimes or only when very naughty. When growing up, respondents reported that in 974 homes with cats and/or dogs, the pets were hit in $20.2 \%$ of them.

\section{Childhood harm towards animals and links to household behaviours}

While this paper focused on the harm children inflicted on animals, it is instructive to examine the home environment of both children who did, and did not, harm animals. Below, we look at some characteristics of the home and their relationship with the types of animal harmed by children (our respondents when a child).

When respondents harmed more than one class of animal, invertebrates (mosquitoes, cockroaches etc.), cold vertebrates (fish, snakes, frogs, lizards etc.), warm vertebrates (cats, dogs etc.), they were classified by the highest group of animal hurt, with invertebrates considered the lowest and warm vertebrates the highest class of animal. The level of corporal punishment used to discipline the child was linked to the class of animals harmed. Only $13.5 \%$ of respondents 
who had never been hit hurt warm vertebrates, as opposed to $34.8 \%$ of those who were hit often, $\chi^{2}(12, N=1,434)=43.3, p<$ .001 .

Interpersonal violence towards the child's mother was associated with a greater chance of the child harming animals, $O R=1.65$ (mother hit v mother not hit), 95\% CI [1.26, 2.16], a lack of physical violence towards the mother was associated with the child being less likely to harm animals, $\chi^{2}(3, \mathrm{~N}=1,400)=$ 13.7, $p=.003$ ).

Domestic violence in the home was associated with children being more likely to harm animals than children from homes where domestic violence was absent, $O R=1.82$ (domestic violence present vs. domestic violence absent), 95\% CI [1.45, 2.28]. Further, the animal victim was more likely to be a warm vertebrate when the child lived in a home with domestic violence than when she or he lived in a home without domestic violence, $\chi^{2}(3, N=1,303)=39.8, p<.001$.

The presence of a gun in the home (yes or probably yes) was linked with childhood harm to animals, $\chi^{2}(3, \mathrm{~N}=1,308)=14.2, p=$ $.003, O R=1.38$ (gun vs. no gun in home), 95\% CI [1.06, 1.79]. In homes without guns, proportionately more respondents indicated that had never harmed animals, while those in homes with guns were more likely to have harmed warm vertebrates, see Table 2.

Table 2

Associations between violence, and a firearm in the home and the class of animal harmed.

\begin{tabular}{|c|c|c|c|c|c|c|}
\hline & \multirow[b]{2}{*}{ Response: } & \multicolumn{4}{|c|}{ Highest level of animal harmed } & \multirow[b]{2}{*}{$\mathrm{N}$} \\
\hline & & None & Invertebrates & $\begin{array}{c}\text { Cold } \\
\text { vertebrates }\end{array}$ & $\begin{array}{c}\text { Warm } \\
\text { vertebrates }\end{array}$ & \\
\hline \multirow{6}{*}{$\begin{array}{l}\text { Use of violence to } \\
\text { discipline the } \\
\text { respondent as a child }\end{array}$} & No, never & $59.6 \%$ & $16.3 \%$ & $10.6 \%$ & $13.5 \%$ & 104 \\
\hline & Yes, only when very naughty & $39.4 \%$ & $17.0 \%$ & $20.6 \%$ & $23.0 \%$ & 578 \\
\hline & Yes, sometimes & $38.6 \%$ & $13.9 \%$ & $23.4 \%$ & $24.1 \%$ & 402 \\
\hline & Yes, often & $30.3 \%$ & $14.6 \%$ & $20.2 \%$ & $34.8 \%$ & 287 \\
\hline & abuse & $34.9 \%$ & $15.9 \%$ & $20.6 \%$ & $28.6 \%$ & 63 \\
\hline & Overall & $38.9 \%$ & $15.6 \%$ & $20.6 \%$ & $25.2 \%$ & 1,434 \\
\hline \multirow{3}{*}{$\begin{array}{l}\text { Mother hit by } \\
\text { intimate partner } \\
\text { when respondent } \\
\text { was a child }\end{array}$} & No, or probably no & $40.9 \%$ & $15.2 \%$ & $19.4 \%$ & $24.5 \%$ & 1082 \\
\hline & Yes, or probably yes & $29.6 \%$ & $17.0 \%$ & $23.9 \%$ & $29.6 \%$ & 318 \\
\hline & Overall & $38.4 \%$ & $15.6 \%$ & $20.4 \%$ & $25.6 \%$ & 1,400 \\
\hline \multirow{3}{*}{$\begin{array}{l}\text { Domestic violence in } \\
\text { home } \\
\text { of respondent when } \\
\text { a child }\end{array}$} & No & $45.2 \%$ & $16.0 \%$ & $19.0 \%$ & $19.8 \%$ & 832 \\
\hline & Yes & $31.2 \%$ & $13.8 \%$ & $23.0 \%$ & $31.9 \%$ & 551 \\
\hline & Overall & $39.6 \%$ & $15.1 \%$ & $20.6 \%$ & $24.7 \%$ & 1,383 \\
\hline \multirow{3}{*}{$\begin{array}{l}\text { Gun(s) in the } \\
\text { child's home }\end{array}$} & No & $40.7 \%$ & $16.1 \%$ & $19.8 \%$ & $23.3 \%$ & 968 \\
\hline & Yes & $33.2 \%$ & $13.5 \%$ & $20.0 \%$ & $33.2 \%$ & 340 \\
\hline & Overall & $38.8 \%$ & $15.4 \%$ & $19.9 \%$ & $25.9 \%$ & 1,308 \\
\hline
\end{tabular}

\section{Childhood actions towards animals}

The majority of respondents had hurt animals on purpose as only $36.8 \%$ (of 1,558) indicated that they had never hurt an animal.
Overall, 2.5\% (of 1,463) thought that it was fun for people to hurt animals; $60.4 \%$ were very sad and upset and $33.4 \%$ did not know how they felt; the remaining respondents 
thought that the animals deserved it. Male respondents were more likely than females to have hurt animals frequently and less likely to have never hurt animals, $\chi^{2}(4, \mathrm{~N}=1,435)=$ 108.3, $p<.001$, (Table 3). Of those who harmed animals, 11.7\% (of 907 respondents) recalled being punished for the act. Male respondents were more likely than female respondents to have harmed cold and warm vertebrates and females were more likely than males to harm invertebrates, $\chi^{2}(2, \mathrm{~N}=879)=$ 44.6, $p<.001$, (Table 3).

Table 3

Frequency of intentional harm to animals and class of animal harmed, percentages within sex.

\begin{tabular}{|c|c|c|c|c|}
\hline & & Female & Male & Overall \\
\hline \multirow{5}{*}{$\begin{array}{l}\text { Frequency of intentional harm of } \\
\text { animals in childhood }\end{array}$} & Never & $47.5 \%$ & $22.7 \%$ & $38.7 \%$ \\
\hline & Hardly ever & $24.1 \%$ & $24.7 \%$ & $24.3 \%$ \\
\hline & A few times & $17.8 \%$ & $32.4 \%$ & $22.9 \%$ \\
\hline & Several times & $7.8 \%$ & $11.9 \%$ & $9.2 \%$ \\
\hline & Frequently & $2.9 \%$ & $8.3 \%$ & $4.8 \%$ \\
\hline \multirow{5}{*}{$\begin{array}{l}\text { Class of highest animal intentionally } \\
\text { harmed in childhood }\end{array}$} & $N$ & 929 & 506 & 1,435 \\
\hline & Invertebrate & $33.6 \%$ & $14.6 \%$ & $25.1 \%$ \\
\hline & Cold vertebrate & $32.0 \%$ & $35.5 \%$ & $33.6 \%$ \\
\hline & Warm vertebrate & $34.4 \%$ & $49.9 \%$ & $41.3 \%$ \\
\hline & $N$ & 488 & 391 & 879 \\
\hline
\end{tabular}

When considering harm inflicted on creatures, the harm towards warm vertebrates we considered to be of greatest concern. When the type of animal harmed was considered,

Table 4

Percentages of males and females harming selected types of animals by frequency, in the respondent's childhood. (Percentages within sex.)

\begin{tabular}{rrrrrrrrrrrr}
\hline & \multicolumn{3}{c}{ Wild animals } & \multicolumn{2}{c}{ Stray dogs \& cats } & Other stray animals & & Farm animals & Pet animals \\
\hline $\begin{array}{r}\text { Frequency of harm, } \\
\text { number of times }\end{array}$ & Female & Male & Female & Male & Female & Male & Female & Male & Female & Male \\
\hline 0 & $63.5 \%$ & $40.1 \%$ & $33.4 \%$ & $23.9 \%$ & $59.2 \%$ & $53.4 \%$ & $82.6 \%$ & $80.8 \%$ & $65.3 \%$ & $61.4 \%$ \\
1 to 5 & $23.8 \%$ & $38.6 \%$ & $50.4 \%$ & $46.5 \%$ & $28.3 \%$ & $30.5 \%$ & $8.8 \%$ & $10.6 \%$ & $27.7 \%$ & $27.5 \%$ \\
6 to 10 & $6.1 \%$ & $9.7 \%$ & $9.8 \%$ & $14.4 \%$ & $7.3 \%$ & $9.1 \%$ & $4.4 \%$ & $5.5 \%$ & $4.0 \%$ & $5.7 \%$ \\
11 to 15 & $3.0 \%$ & $4.4 \%$ & $1.2 \%$ & $3.7 \%$ & $1.2 \%$ & $2.3 \%$ & $2.6 \%$ & $2.1 \%$ & $0.8 \%$ & $2.0 \%$ \\
Over 15 & $3.6 \%$ & $7.2 \%$ & $5.2 \%$ & $11.5 \%$ & $4.1 \%$ & $4.7 \%$ & $1.5 \%$ & $1.0 \%$ & $2.3 \%$ & $3.4 \%$ \\
$N$ & 357 & 317 & 401 & 353 & 338 & 296 & 335 & 290 & 349 & 296 \\
\hline
\end{tabular}

The open-ended questions, about what happened when the animal was harmed, were themed. Females and males reacted differently to the animals, $\chi^{2}(3, \mathrm{~N}=583)=$ $11.1, p=.011$ (Table 5). We noted earlier that females were more likely to harm stray cats and dogs were the most likely victims. Farm animals were the least likely to be harmed (Table 4). 
Table 5

Themed reactions of participants, in their childhood, to treating animals which they had harmed.

\begin{tabular}{lrrr}
\hline & \multicolumn{3}{c}{ Sex } \\
\hline & Female & Male & Overall \\
\hline $\begin{array}{l}\text { Shoo the animal } \\
\text { away }\end{array}$ & $1.5 \%$ & $2.0 \%$ & $1.7 \%$ \\
$\begin{array}{l}\text { Injure the animal } \\
\text { Kill the animal }\end{array}$ & $31.9 \%$ & $40.2 \%$ & $35.5 \%$ \\
$\begin{array}{l}\text { Enjoy the killing or } \\
\text { torture }\end{array}$ & $14.5 \%$ & $19.5 \%$ & $16.6 \%$ \\
$N$ & 332 & 251 & $58.2 \%$ \\
\hline
\end{tabular}

The reactions of respondents to their abuse of animals in childhood ranged from remorse and an understanding that in later life they appreciated that their treatment of animals had been wrong to some respondents clearly having enjoyed the experience of intentional harm.

These reactions were themed and showed that females were more likely than males to express sorrow for their harm of animals, $\chi^{2}(3, \mathrm{~N}=588)=50.3, p<.001$, (Table 6).

Table 6

Themed reactions to respondent's violence towards animals

\begin{tabular}{|c|c|c|c|}
\hline \multicolumn{4}{|c|}{ Sex } \\
\hline & Female & Male & Total \\
\hline $\begin{array}{l}\text { Hurting animals } \\
\text { is wrong }\end{array}$ & $47.7 \%$ & $22.6 \%$ & $39.6 \%$ \\
\hline $\begin{array}{l}\text { Sorrow } \\
\text { expressed }\end{array}$ & $16.1 \%$ & $34.7 \%$ & $22.1 \%$ \\
\hline $\begin{array}{l}\text { No sorrow } \\
\text { expressed } \\
\text { Gave pleasure }\end{array}$ & $35.9 \%$ & $39.5 \%$ & $37.1 \%$ \\
\hline $\begin{array}{l}\text { or } \\
\text { entertainment }\end{array}$ & $0.3 \%$ & $3.2 \%$ & $1.2 \%$ \\
\hline$N$ & 398 & 190 & 588 \\
\hline
\end{tabular}

\section{The Children and Animals Inventory (CAI)} and links to household behaviours

For those children who harmed animals the CAI was calculated. Overall, males had a higher CAI score than females 21.3 ( $S E=$ 0.32 ), compared to 18.9 ( $S E=0.30$; MannWhitney test, $p<.001, N=596)$. Only $0.3 \%$ of 320 females had a score of over 30 , compared with $4 \%$ of 276 males, Figure 1.

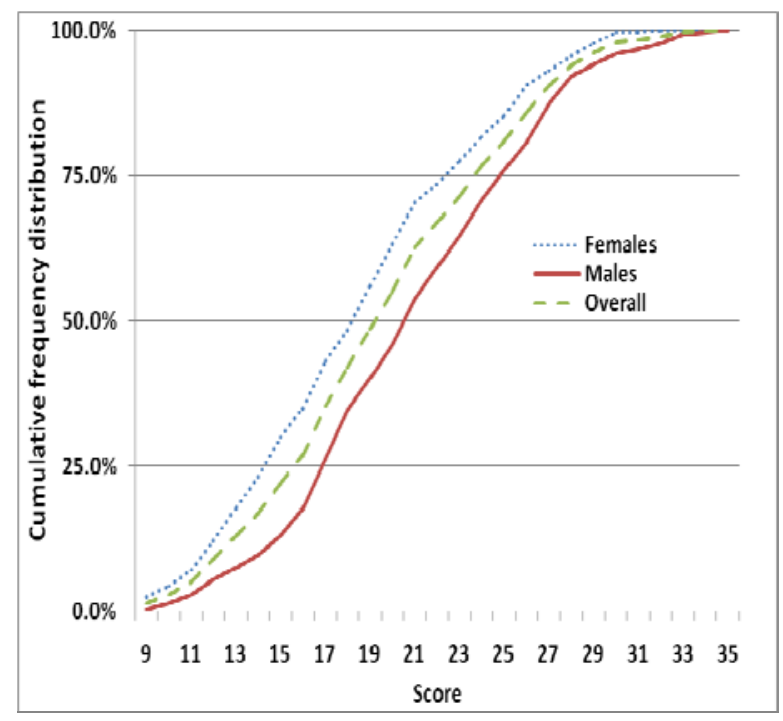

Figure 1: Cumulative distribution of Children and Animals Inventory (CAI) scores by sex.

The CAI scores were compared with a number of behaviors within the household (Table 7). The presence of interpersonal violence, such as children or their mother being hit, was not associated with the CAI score, but violence towards animals, domestic violence and the presence of a gun in the household were associated with the score. When respondents indicated that they lived in a loving home, the mean CAI score was lower $(19.5, S E=0.24)$ compared to homes which were not considered loving $(22.8, S E=0.70$; $p<.001)$.

An analysis of variance to examine the mean CAI scores and the factors in Table 7, indicated that only the sex of the respondent $(p<.001)$, the presence of a firearm in the household $(p=.003)$, hitting animals in the home $(p=.011)$ and the presence of domestic violence $(p<.001)$ were significant. 
Table 7

Mean Children and Animals Inventory (CAI) scores of respondents in whose homes selected behaviours occurred.

\begin{tabular}{|c|c|c|c|c|c|}
\hline \multirow[b]{2}{*}{ Behaviour } & \multicolumn{2}{|c|}{ Yes } & \multicolumn{2}{|c|}{ No } & \multirow[b]{2}{*}{$p$} \\
\hline & Mean & SE & Mean & SE & \\
\hline $\begin{array}{l}\text { As a parent, I } \\
\text { hit my child or } \\
\text { children }\end{array}$ & 21.9 & 0.48 & 20.8 & 1.12 & .356 \\
\hline $\begin{array}{l}\text { A gun in the } \\
\text { household }\end{array}$ & 21.8 & 0.45 & 19.2 & 0.27 & $<.001^{*}$ \\
\hline $\begin{array}{l}\text { Animals hit in } \\
\text { the household }\end{array}$ & 21.8 & 0.52 & 19.4 & 0.26 & $<.001^{*}$ \\
\hline $\begin{array}{l}\text { Domestic } \\
\text { violence }\end{array}$ & 21.3 & 0.33 & 18.8 & 0.29 & $<.001^{*}$ \\
\hline $\begin{array}{l}\text { Children hit in } \\
\text { the home, } \\
\text { when } \\
\text { respondent } \\
\text { was a child }\end{array}$ & 20.8 & 0.39 & 19.6 & 0.27 & .020 \\
\hline $\begin{array}{l}\text { Mother hit by } \\
\text { husband or } \\
\text { partner }\end{array}$ & 20.6 & 0.46 & 19.8 & 0.26 & .142 \\
\hline
\end{tabular}

Acts of violence towards non-sentient animals

Insects were typically killed using chemical or physical means. Respondents expressed a wide range of reactions to their acts of harm towards animals in their childhood. Those who reported hurting insects often justified their actions on the basis that insects (such as mosquitoes and cockroaches) were considered as a threat to the respondent; respondents made a distinction between the perceived justified harming of insects and animals. Others experimented on animals (such as putting salt on frogs) and other pretended to be doctors and so needed patients on which to operate. Some acts of harm, such as killing snakes, were motivated by the erroneous belief that the snake was venomous and so could kill a human (e.g., "In Bahamian culture you were encouraged to kill snakes and insects because they were considered dangerous") or by religious views (e.g., "Bible says were evil").

\section{Acts of violence towards dogs}

Larger animals were attacked with rocks, stones or sticks, and in some cases guns or slingshots. While a range of animals were the subject of abuse, we focus on the open-ended questions which referred to dogs, as dogs (and cats) were the most commonly abused warm vertebrate (Table 3) and as a sentient animal, their harm is of most concern. When asked about the harmful action and its outcome on the dog, 166 responses were given which related to dogs. Of these, $50 \%$ indicated that it was a stray (free-roaming) dog which was the victim. The two most common reasons for harming these dogs were that they were tipping over the garbage or were threatening the respondent. Stones (rocks) and similar items were the most common weapons used to harm the dog. Poison was mentioned only once. Two persons harmed dogs by hitting them with the door of a moving vehicle. One respondent used a BB-gun to shoot at dogs, another "throw boiling water on a stray dog that kept defecating and sleeping in my garage." One boy, who lived in a home with domestic violence used to "put meat on a fishing line with a hook, and lure stay [sic] cats or dogs and eventually kill them." Pet dogs were also at risk of being hit during training for not behaving as required or appearing to be threatening.

\section{Reactions towards violent acts on animals}

Many respondents indicated various levels of remorse or excuses for their childhood actions of harm towards animals. Others were in keeping with comments such as:

Many of the 'animals' i 'hurt' were because they were sick, or because they deserve it ... they may not have the thought process to know right from wrong but $\mathrm{i}$ believe then that $i$ have the right of a 'dominant' species to decide how to deal with the situation.

Harm of insects was typically not associated with remorse as they were considered a public health threat or a source of discomfort or danger. 
One respondent seemed to sum up the reactions of many:

As a child: Bird-felt great sorrow afterwards Snkes [sic] — no remorse-they deserved it because they were as the Bible says were evil crucified a frog-feeling of guilt killed a frog with a fire crackerfeeling of guilt worms - no remorse - they caused you to take worm medicine Dogshit with stones-when they were aggressive or I thought threatened mealthough I detested anyone hurting my dogs.

Some respondents cited religious belief to justify their action toward animals, beyond that of snakes noted earlier. One respondent noted, for example, that "God gave man dominion over animals. We can do with them what we wish. They do not have souls. Thus killing them is like killing grass". However, others believed that "God will judge us for everything we do, he didn't create animals for person[s] to abuse and mistreat" or "am sure GOD placed them there for a reason an[d] they too should serve there suppose [purpose], without having to loss a life by selfish person like those who choose to harm an[d] destroy them". One respondent even quoted Christian scriptures, stating:

It's certainly an act [harm of animals] that Jehovah God does not approve since we are all; including animals, his creation (Proverbs 12:10). The righteous one is caring for the soul of his domestic animal, but the mercies of the wicket [sic] ones are cruel.

\section{Textual analysis}

Respondents' answers to the question: Is there anything else you wish to tell us about your acts of cruelty towards animals? were subjected to discourse analysis using interpretative and quantitative corpuslinguistic methods. The researchers noted the relatively high rate of the word fun in respondents' answers. Given the concern that can be associated with the treatment of animals being considered fun, this was examined further. Fun was a response that was associated with the childhood actions of harm towards animals, and suggested a lack of appreciation of the consequences to the animal of the harmful act. "Just for fun", "it was fun" or similar phrases were linked to a past tense which indicated that these actions have been reevaluated in adulthood. Fun was also used by respondents to identify persons who may suffer from psychological problems, "If people hurt animals for fun, this is sick". Thus respondents expressed a clear distinction between fun as a child and fun as an adult in response to hurting animals.

The word just was commonly used in an apparent rationalization of the actions towards animals. For example, respondents noted variously that: "I would not just hit them for the fun of it"; "I said its just a part of growing up"; "they were just being annoying." Consequently, respondents tended to down play their actions as a child and this again could be associated with an adult realization of the full implications of what they had done as a child. The tendency to invoke the notion "it's just an animal" to rationalize poor treatment of animals has been analyzed extensively by De Soete (2010).

Four-word N-grams (that is, frequently occurring strings of four words within the responses) in the responses to the Is there anything else...? question revealed the concern which the respondents had, as adults, to harming animals. The reoccurrence of the string "[people who harm] animals should be punished" is particularly interesting. Moreover, respondents consistently invoked a divide between cats and dogs and lower orders of animals; that is to say, this divide, although seemingly commonsense, does exist and is an important one for Bahamian respondents. The $\mathrm{N}$-grams also indicated that 
fear (e.g., "afraid of them and" [frequency 4], "am afraid of them" [frequency 3]) was a justification for the acts of harm.

\section{DISCUSSION}

\section{Limitations}

The sample had an over-representation of participants from New Providence and females. Points of comparison with a paper survey (Brennen, Fielding et al., 2010) indicate broadly similar findings: occurrence of domestic violence in homes of respondents aged under 21 years, 33.8\% (in this study $41.3 \%$ of respondents aged 18-21 years); percentage of children not subject to corporal punishment, $14.8 \%$ (this study $7.3 \%$ ); percentage of children abused as a result of corporal punishment, $4.1 \%$ (this study $4.4 \%$ ); percentage of homes with pets in which pets were hit, $24.9 \%$ (this study 20.2\%). In addition to the biases inherent in any nonprobabilistic sample which may make it unrepresentative of The Bahamas as a whole, the reliability of the answers depends upon the recall ability of respondents. However, many of the respondents were either teenagers or in their early twenties so this should have minimized this error. Further, the method of administration of the survey (e-mail) would permit private reflection on the questions which could allow for more reliable recall than may have occurred in a face-to-face interview.

The study used the standard Children and Animals Inventory (Dadds et al., 2004) with little modification. As pointed out recently by Paganini et al., (2010), such measures may need to be localized for community differences and there is a need to understand what actions are regarded as cruel at a community level. This suggests that future research in The Bahamas should look at these aspects in further detail.

\section{Associations with violence in the home}

Violence towards animals and humans within respondent homes was common, with over
$90 \%$ of respondents being subjected to corporal punishment as a child. Intimate partner violence occurred in over $20 \%$ of homes as did violence towards pets (when present). Domestic violence occurred in almost $40 \%$ of respondent homes, when the respondents were children. The association between violence towards the child and animal abuse was consistent with the observations made by Flynn (1999) in another community (South Carolina in the United States) where corporal punishment is widespread. It is of interest to note that The Bahamas and Carolinas share a common heritage, as Loyalists and their slaves migrated from the Carolinas to The Bahamas in the 1780's (Craton \& Saunders, 1992).

The violent environment which our respondents reported can cause stress upon children and result in low self esteem (Maundeni, 2000). Further, this violent background, particularly if the child is abused can heighten the risk of the child's being abusive towards animals (Ascione, Friedrich, Heath, \& Hayashi, 2003). Our results are in general agreement with those reported by Yamazaki (2010) from Japan who found that maltreated children perpetrated more serious acts of abuse than non-maltreated children.

The association of children being exposed to domestic violence and also being cruel towards animals has also been demonstrated in Canada (Currie, 2006) and was clearly indicated by the boy living in a home with domestic violence and who baited dogs and killed them. The homes of those respondents who did not report harming animals in their childhood were less violent homes than those in which children had harmed animals. In addition, the presence of a gun in a household was also linked with childhood harm of animals which confirms the findings of Brennen, Fielding et al. (2010) which showed that the presence of a gun in a Bahamian household is associated with a number of 
undesirable behaviours, not just domestic violence.

These associations indicate that harm of animals by children may be influenced by the nurturing of the child, the way she or he is treated and the events to which she or he is exposed. This is consistent with the findings of Duncan, Thomas and Miller (2005) who found that abuse of children (sexual or physical or both) and domestic violence in the home may contribute to such children harming animals. While our findings are not new in themselves (e.g., Flynn, 1999), they show that they also apply to a post-colonial Afro-Caribbean community. They suggest that until society changes its attitudes towards violence in the home, childhood harm of animals will not diminish.

\section{Harm towards animals}

The results indicated that most participants had harmed animals at some stage during their childhood and some had derived pleasure from the harm. As might be expected, insects, such as mosquitoes and cockroaches were the most commonly harmed class of animal. This harm was justified by respondents deeming the insects as being harmful and so they needed to protect themselves from the insect. These reactions can be based on valid public health issues, particularly in the case of mosquitoes (Centers for Disease Control and Prevention, 2010).

While harm to insects is not always considered an animal welfare issue, their harm could be a neglected aspect of animal welfare (Aluja, 2007) and possibly provide a pathway to the harm of more complex creatures. In the case of cold vertebrates, the fear of frogs, lizards and snakes, all of which in The Bahamas are harmless to humans, was noted. Bahamian children appeared to share a fear of frogs in common with their South African counterparts (Gordon, 2007). However, according to Conant, Stebbins and
Collins (1992) "we now know that the fear of reptiles and amphibians is not instinctive, but is learned by children, usually from people who are simply uninformed" (p. 4), and so this suggests that education could be effective in reducing the number of incidences of harm that children cause non-human animals. It would be instructive to find out the mechanism by which children are taught to fear, or rationalize the harm, of harmless creatures in The Bahamian context. It is conceivable that Bahamian children, like those in the United Kingdom, learn how to respond to animals from their caregivers (Howard \& Vick, 2010), which would point to the need to teach adults how to interact with animals, so that they can in turn teach children. These findings may also reflect the "traditional distinction between acceptable and unacceptable cruelty" (Pagani et al., 2010, p. 261) in The Bahamas. As such it invites us to further assess what acts constitute cruelty or harm in an AfroCaribbean community as these have only been touched upon in the case of $\operatorname{dogs}$ (Fielding et al., 2005).

While many types of creature had been mistreated, stray cats and dogs were the warm-blooded animals participants mistreated most often. Boyd et al. (2004) found that fear of dogs, as well as their being a nuisance, were reasons dogs are disliked, and so fear of dogs, as indicated, in some of the open-ended questions, may have caused some respondents to harm dogs. Fielding (2009) found that dogs are considered to be the most important neighbourhood nuisance in The Bahamas, which probably puts them at risk of harm, and in another study $25 \%$ of respondents either had been bitten or knew of a family member who had been bitten by a stray dog (Fielding et al., 2005).

Further, Fielding (2008a) indicated that not all Bahamian adults agreed that animals feel pain, and this may condition views as to the 
acceptability of harmful acts towards these animals. Roaming dogs, and to a lesser extent, cats, are common (Fielding, 2009). Therefore, there are many opportunities for children to harm these animals, and if they feel that the animals have no owner, they may think that they will be certain to escape punishment. Relatively few respondents were punished for harming animals, which supports this conjecture. A consequence of the limited care offered animals which results in their roaming the street, not only puts the animals at risk of harm, from motor vehicles etc., but provides opportunities for children to practice or learn harm. The finding that roaming domestic pets, rather than owned pets, were particularly at risk of being harmed is broadly similar to findings in the United States where companion animals (probably not roaming) were most at risk, and dogs were at greater risk than cats (Humane Society of The United States, 2004).

Reports of children harming roaming dogs in school grounds are a cause for concern, particularly when such acts go unpunished (Fielding et al., 2005). Further, Henry and Sanders (2007) demonstrated the link between children who abuse animals and bullying in school, which again shows the need for realization at school and in the home of the significance of children harming animals. The fact that few respondents were punished for harming animals, probably reflects the common practice of using violence to train pets (Fielding, 2010a) and the presence of other violent behaviours in Bahamian homes (Brennen, Fielding et al., 2010). We could conjecture that in such a mix of household violence, only extreme violence towards animals may be considered worthy of punishment of the child. Further, the lack of enforcement of the laws concerning animal welfare (Fielding et al., 2005), can lead to society not viewing harm to animals as seriously as may be desirable and so result in adults not censuring children for harming animals.

\section{Gender and harm of animals}

While some $16.6 \%$ of respondents who hurt animals enjoyed harming them at the time, only about $1 \%$ seemed to have a persistent feeling of enjoyment. These figures give us an idea of the number of people who may be at risk of being potential threats to society. The results also indicate that in an AfroCaribbean society, when children harmed animals, males had higher CAI scores, an observation in keeping with other studies in the United States (among others, Flynn, 2001) and in Japan, where male children were more likely than female children to abuse animals (Yamazaki, 2010). However, this link between sex and animal abuse has not been reported by all researchers (Currie, 2006). Consequently, our findings echo the commonly observed fact that males are more aggressive and more adventurous than females (Lips, 2008); clearly this can lead them to be more likely to perpetuate as well as explore the consequences of harmful acts on animals. As pointed out by Oleson and Henry (2009), male hostility and the need for power are related to animal cruelty. The data also suggested then when children harmed animals, interpersonal violence was common (not associated with the CAI), but the presence of guns, domestic violence and violence towards animals were associated with higher CAI scores, suggesting that these activities may have some bearing as to how children interact with animals.

When the smaller group of respondents who described the act of harm was investigated, no difference between the sexes was observed. Once the type of animal harmed was taken into account, the consequence of the harm inflicted on animals was similar for both sexes. So while proportionately more males than females harmed animals, the result of the harm on the different classes of animal was 
similar for both sexes. So as far as the animal victim is concerned, both males and females are equally dangerous.

Females were more likely to show regret than males, and they were less likely than males to claim to have enjoyed harming animals. These findings are in keeping with other studies which indicated sex differences between children and animal cruelty (Dadds, Whiting, \& Hawes, 2006) and sex and empathy towards animals (Daly \& Morton, 2006; Rudy, 2008). These observations and the fact that males, rather than females, were more likely to harm warm vertebrates are congruent with the fact that Bahamian males are more likely than females to be associated with violent crimes in adulthood (Hanna, 2011). These associations and those in the wider literature on aggression in males, suggests that the parenting, particularly of males, needs special care to ensure that adult males are empathic towards humans (American Academy of Child and Adolescent Psychiatry, 2001) and non-human animals.

\section{Violence towards humans and animals}

The high rate of violent behaviours in Bahamian homes has already been commented upon by McEwen (2010). The use of violence to train pets is common (Fielding, 2010c) and as indicated by our respondents, caregivers may have unrealistic expectations of their dogs, (Carlisle-Frank, Frank, \& Nielsen, 2004) or misinterpret dog barks as threatening (Taylor, Reby, \& McComb, 2010) which can lead to violence towards the animals. The fact that some forms of violence in the home were not linked with the CAI scores indicates that they occurred widely throughout Bahamian homes.

As pointed out by social welfare researchers, the association between the treatment of children and animals has important implications for child protection services (Risley-Curtiss, Zilney, \& Hornung, 2010). The idea that empathy towards all living creatures is important means that programmes must be put in place to protect children in homes where animals are mistreated, and to help those children who may have learnt or who display inhumane tendencies. However, until Bahamian government agencies themselves appreciate the scale and scope of behaviours which are linked with the harm of animals, they may be reluctant to spend scarce resources on matters which appear to be unimportant, such as the treatment of animals. When such programmes are designed, it will be important that similar messages are delivered to both male and female participants as both sexes harmed animals. Further, parents and peers will need to be encouraged to attend so that they can act as appropriate role models for children.

Other factors which influenced the CAI score were domestic violence and the presence of a gun in the home. Earlier studies have shown that domestic violence is linked with harm of animals, both in The Bahamas (Fielding \& Plumridge, 2010) and first-world communities (Ascione \& Arkow, 1999) while the presence of a gun in a home has been linked by Doherty and Hornosty (2008) to domestic violence in rural Canada where many homes included hunters. In The Bahamas, the most likely firearm for which a resident may obtain a license is a shotgun for hunting. Therefore, homes in which shooting animals is considered a sport, may generate less empathic feeling towards animals which are learnt by children and so are reflected in higher CAI scores. Although Flynn (2002) found no difference in empathy towards animals between hunters and non-hunters, hunters were more likely to have been cruel towards animals. His study suggested that hunters behave differently towards animals and this may influence the actions and attitudes of other household members, including children. The more violent nature of hunters noted by Flynn may explain why a 
gun in the household is associated with other violent behaviours such as domestic violence. In the United States, men charged with domestic violence are likely to have their weapons (guns, etc.) confiscated (Sliwinski, 2007), which indicates the concerns police have about even possible perpetrators of domestic violence owning guns. Given the association found in this study, and the fact that many guns in The Bahamas are probably owned illegally (Brennen, Carroll et al., 2010), the Bahamian community may wish to reconsider the granting of gun licenses, even for hunting, given that most of the population live in an increasingly urban environment with significantly diminishing opportunities for hunting safely.

\section{Reactions towards violence towards animals}

Historically, religious groups have played an important role in animal protection in The Bahamas as leaders in the Christian community were at the forefront of setting up the first animal welfare organization in Victorian times (Fielding et al., 2005). In a country where most residents claim a religious affiliation (Bahamas Department of Statistics, 2002), it is not surprising that faithbased issues were used to justify the treatment of animals. The debate about religious belief being harmful or otherwise to the treatment of animals continues (e.g., Kaufman, 2010), and the use of Biblical references within our respondent group indicates that within The Bahamas, the debate would be lively. Presently it is not known if religious attitudes towards animals in The Bahamas are changing, as they are in other parts of the world (BBC Religions, 2009), but it they do, believers may be expected to enhance their level of care towards animals. However, given the important role of religion in The Bahamas, religious leaders could be highly influential in encouraging their congregations to follow the Golden Rule, of treating animals how they themselves would wish to be treated. Given the large number of Christian churches in The Bahamas, it would be useful to find out if any local differences exist in the teachings of these different denominations towards animals and if these teachings are observed.

Many respondents appreciated that their childhood actions towards animals were often misguided with only $2.5 \%$ thinking it was fun for people to harm animals. The open-ended questions indicated that the respondents, as adults, now appreciated that their childhood actions which may have been considered fun needed to be re-evaluated but, even while explaining their youthful actions the word just was used to down play their harmful acts. The importance of the word just in relation to animals has been explored by, among others, De Soete (2010).

The open-ended questions also showed that respondents thought that those who harmed animals should be punished, a finding consistent with local newspaper articles, and the associated emailed reactions (Nunez, 2010) as well as a 2009 study by Taylor and Signal in Australia. These reactions point to the need to educate children at an early age that what is considered just fun to them can have severe consequences to animals and so build empathy towards animals at an early age. In other words, Bahamian educators must instil in children the importance of caring for animals so that they do not commit acts they may later regret.

The corpus linguistic approach to the qualitative information allowed the authors to identify ways in which respondents excused previous behaviour, which may otherwise have been overlooked. That is to say, it allowed patterns to be identified in the openended responses that might otherwise have been missed. The use of words (e.g., stray) with respect to treatment of animals (Stibbe, 2001) and acceptance of the responsibility of 
care (Fielding, 2008c) is important in aiding understanding of how humans interact with nonhuman animals. Based on our experience with analyzing our data, cross-cultural comparisons may be enriched by wider use of corpus linguistic methods. Moreover, corpus linguistic methods can be particularly useful to quickly sort through and categorize large amounts of open-ended response data, like that provided by online survey platforms.

\section{CONCLUSION}

This study confirms that many respondents, when children, in the study group were brought up in homes where violence occurred, either towards humans or non-human animals. The literature would suggest that this exposure of Bahamian children to violence would put them at risk of harming animals. This study confirms that male children are more likely to harm animals than female children. Stray animals in particular were at particular risk of being harmed. It would appear that there is a need to develop empathy in people towards all living animals, as advocated by DeViney, Dickert and Lockwood (1986) and to educate adults about the real health threats that animals can pose humans so that people can protect themselves without harming the animals themselves.

In addition to the avenues for future research noted above, further research needs to examine acceptable and unacceptable animal abuse in Bahamian society (this type of study could be based on Pagani, Robustelli, and Ascione, 2007) as well as how animals are portrayed and discussed in schools and homes.

\section{REFERENCES}

Aluja, A. (2007, July). Insect welfare: Should we care? In F. Galindo \& L. Alvarez (Eds.), Proceedings of the $41^{\text {st }}$ International Congress of the ISAE, Merida, Mexico, (p. 3). Mexico: International Society for Applied Ethology. Retrieved from http://www.mediafire.com/?xo5i4li2c2dm86z

American Academy of Child \& Adolescent Psychiatry (2001). Understanding violent behavior in children \& adolescents. Facts for Families, 5. Retrieved from http://www.aacap.org/cs/root/facts for fami lies/understanding_violent_behavior_in_chil dren_and_adolescents

Anthony, L. (2007). AntConc (Version 3.2.1w, Windows 2007) [Computer software]. Tokyo: Author.

Aranha, K. (2009). Put a little love in your heart. The Bahamas Weekly. Retrieved from http://www.thebahamasweekly.com/publish/ the-pet-pages/Put_a_Little_Love_in_Your005939.shtml
Arluke, A. (2007). Cruelty to animals.

Harming animals and its impact on people. In M. Bekoff (Ed.), Encyclopedia of humananimal relationships (pp. 416-419).

Westport, CT: Greenwood.

Ascione, F. R. (Ed.). (2008). The international handbook on animal abuse and cruelty: Theory, research, and application. West Lafayette, IN: Purdue University Press.

Ascione, F. R., \& Arkow, P. (Eds.). (1999). Child abuse, domestic violence, and animal abuse: Linking the circles of compassion for prevention and intervention. West Lafayette, IN: Purdue University Press.

Ascione, F. R., \& Shapiro, K. (2009). People and animals, kindness and cruelty: Research directions and policy implications. Journal of Social Issues, 65, 569-587. doi:10.1111/j.1540-4560.2009.01614.x

Ascione, F. R., Friedrich, W. N., Heath, J., \& Hayashi, K. (2003). Cruelty to animals in normative, sexually abused, and outpatient 
psychiatric samples of 6- to 12-year-old children: Relations to maltreatment and expose to domestic violence. Anthrozoös: A Multidisciplinary Journal of the Interactions of People \& Animals, 16, 194-212. doi:10.2752/089279303786992116

Azrael, D., \& Hemenway, D. (2000). 'In the safety of your own home': Results from a national survey on gun use at home. Social Science \& Medicine, 50, 285-291. doi:10.1016/S0277-9536(99)00283-X

Bahamas Department of Statistics (2002).Report on the 2000 census of population \& housing. Nassau, Bahamas: Ministry of Finance.

Bahamas High Commission. (2009). The Commonwealth of the Bahamas fauna and flora. London, England: Author. Retrieved from http://www.bahamashclondon.net/ uploads/Fact_Sheet_on_Fauna.pdf

Bahamas Ministry of Education, \& College of The Bahamas (2009). [Survey of school children in The Bahamas]. Unpublished raw data.

BBC Religions (2009, August 3). Animal rights. Retrieved from http://www.bbc.co.uk/religion/religions/chri stianity/christianethics/animals_1.shtml

Beirne, P. (2004). From animal abuse to interhuman violence? A critical review of the progression thesis. Society \& Animals: Journal of Human-Animal Studies, 12, 3965. doi:10.1163/156853004323029531

Bevan, E., \& Higgins, D. J. (2002). Is domestic violence learned? The contribution of five forms of child maltreatment to men's violence and adjustment. Journal of Family Violence, 17, 223-245. doi:10.1023/A:1016053228021

Bland, J. M., \& Altman, D. G. (1997). Cronbach's alpha. British Medical Journal, 314, 572.
Boyd, C. M., Fotheringham, B., Litchfield, C., McBryde, I., Metzer, J. C., Scanlon, P., ... Winefield, A. H. (2004). Fear of dogs in a community sample: Effects of age, gender and prior experience of canine aggression. Anthrozoös: A Multidisciplinary Journal of the Interactions of People \& Animals, 17, 146-166. doi:10.2752/089279304786991800

Brennen, S., Carroll, M. C, Hutchison, D., Minnis, J., Bethel, N., Hanna, C., \& Fielding, W. J. (2010). [Gun ownership in The Bahamas]. Unpublished raw data.

Brennen, S., Fielding, W. J., Carroll, M. C, McCants Miller, J. C, Adderley, L., \& Thompson, M. A. (2010). A preliminary investigation of the prevalence of corporal punishment of children and selected cooccurring behaviours in households on New Providence, The Bahamas. The International Journal of Bahamian Studies, 16, 1-18. Retrieved from http://journals.sfu.ca/cob/index.php/files/arti cle/view/121

Burnett-Garraway, C. H. (2001). Domestic violence a study of the occurrence and predictors in an accident and emergency department, The Bahamas. (Unpublished doctor of medicine thesis). University of the West Indies, Cave Hill, Jamaica.

Carlisle-Frank, P., Frank, J. M., \& Nielsen, L. (2004). Selective battering of the family pet. Anthrozoös: A Multidisciplinary Journal of the Interactions of People \& Animals, 17(1), 26-42. doi:10.2752/089279304786991864

Centers for Disease Control and Prevention. (2010). Health information for travelers to The Bahamas. Retrieved from http://wwwnc.cdc.gov/travel/destinations/th e-bahamas.aspx

Conant, R., Stebbins, R. C., \& Collins, J. T. (1992). The concise field guide to nearly 200 reptiles and amphibians of North America. New York, NY: Houghton Mifflin. 
Craton, M., \& Saunders, G. (1992). Islanders in the stream: A history of the Bahamian people: Vol. 2. From the ending of slavery to the twenty-first century. Athens, GA: University of Georgia Press.

Currie, C. L. (2006). Animal cruelty by children exposed to domestic violence. Child Abuse \& Neglect, 30, 425-435. doi:10.1016/j.chiabu.2005.10.014

Dadds, M. R. (2008). Conduct problems and cruelty to animals in children: What is the link? In F. R. Ascione (Ed.), The international handbook of animal abuse and cruelty: Theory, research, and application (pp. 111-131). West Lafayette, IN: Purdue University Press.

Dadds, M. R., Whiting, C., \& Hawes, D. J. (2006). Associations among cruelty to animals, family conflict, and psychopathic traits in childhood. Journal of Interpersonal Violence, 21, 411-429. doi:10.1177/0886260505283341

Dadds, M. R., Whiting, C., Bunn, P., Fraser, J. A., Charlson, J. H., \& Pirola-Merlo, A. (2004). Measurement of cruelty in children: The Cruelty to Animals Inventory. Journal of Abnormal Child Psychology, 32, 321-334. doi.org/10.1023/B:JACP.0000026145.69556 .d9

Daly, B., \& Morton, L. L. (2006). An investigation of human-animal interactions and empathy as related to pet preference, ownership, attachment, and attitudes in children. Anthrozoös: A Multidisciplinary Journal of the Interactions of People \& Animals, 19, 113-127. doi:10.2752/089279306785593801

De Soete, F. (2010). It's just an animal? A theoretical framework for understanding the emergence of animal categories in the United States. (Doctoral dissertation, University of British Columbia, Vancouver, British Columbia). Retrieved from https://circle.ubc.ca/bitstream/handle/2429/2 5042/ubc_2010_fall_de_soete_francois.pdf? sequence $=1$

DeViney, E., Dickert, J., \& Lockwood, R. (1983). The care of pets within child abusing families. International Journal for the Study of Animal Problems, 4, 321-329.

Doherty, D., \& Hornosty, J. (2008). Exploring the links: Firearms, family violence and animal abuse in rural communities. The Latham Letter, 29(3), 14-17. Retrieved from http://www.latham.org/Issues/LL_08_SU.pd $\mathrm{f}$ tpage $=14 \&$ zoom $=70$

Duncan, A., Thomas, J. C., \& Miller, C. (2005). Significance of family risk factors in development of childhood cruelty in adolescent boys with conduct problems. Journal of Family Violence, 20, 235-239. doi:10.1007/s10896-005-5987-9

Durham, D., \& Merskin, D. (2009). Animals, agency, and absence: A discourse analysis of institutional animal care and use committee meetings. In S. E. McFarland \& R. Hediger (Eds.), Animals and agency: An interdisciplinary exploration. Boston, MA: Brill.

Ellingsen, K., Zanella, A. J., Bjerkås, E., \& Indrebø, A. (2010). The relationship between empathy, perception of pain and attitudes towards pets among Norwegian dog owners. Anthrozoös: A

Multidisciplinary Journal of the Interactions of People \& Animals, 23, 231-243. doi:10.2752/175303710X12750451258931

Fielding, W. J. (2008a). Attitudes and actions of pet caregivers in New Providence, The Bahamas, in the context of their American counterparts. Anthrozoös: A Multidisciplinary Journal of the Interactions of People \& Animals, 21, 351-361. doi:10.2752/175303708X371573

Fielding, W. J. (2008b). Dogs: A continuing and common neighborhood nuisance of New Providence, The Bahamas. Society \& 
Animals: Journal of Human-Animal Studies, 16, 61-73. doi:10.1163/156853008X269890

Fielding, W. J. (2008c). Establishing a typology for dogs in the English speaking Caribbean. College of The Bahamas Research Journal, 14, 13-18. Retrieved from http://journals.sfu.ca/cob/index.php/files/arti cle/viewArticle/96

Fielding, W. J. (2009). A comparison of cat and dog caregivers in New Providence, The Bahamas. Journal of Applied Animal Welfare Science, 12, 31-44. doi:10.1080/10888700802536616

Fielding, W. J. (2010a). Domestic violence and dog care in New Providence, The Bahamas. Society \& Animals: Journal of Human-Animal Studies, 18, 183-203 doi:10.1163/156853010X492024

Fielding, W. J. (2010b). [Determinants of the level of care provided for various types and sizes of dogs in New Providence, The Bahamas]. Unpublished raw data.

Fielding, W. J. (2010c). Determinants of the level of care provided for various types and sizes of dogs in New Providence, The Bahamas. The International Journal of Bahamian Studies, 16, 63-77. Retrieved from http://journals.sfu.ca/cob/index. php/files/article/view/119/128

Fielding, W. J., \& Plumridge, S. J. (2005). Characteristics of owned dogs on the island of New Providence. The Bahamas. Journal of Applied Animal Welfare Science, 8, 245260. Retrieved from http://www.societyandanimalsforum.org/jaa ws/full_articles/8.4/fielding.pdf

Fielding, W. J., Mather, J., \& Isaacs, M. (2005). Potcakes: Dog ownership in New Providence, The Bahamas. West Lafayette, IN: Purdue University Press.

Fielding, W. J., \& Plumridge, S. (2010). The association between pet care and deviant household behaviours in an Afro-Caribbean, college student community in New Providence, The Bahamas. Anthrozoös: A Multidisciplinary Journal of the Interactions of People \& Animals, 23(1), 69-78.

Flynn, C. P. (1999). Exploring the link between corporal punishment and children's cruelty to animals. Journal of Marriage and the Family, 61, 971-981. doi:10.2307/354017

Flynn, C. P. (2001). Acknowledging the "zoological connection": A sociological analysis of animal cruelty. Society \& Animals: Journal of Human-Animal Studies, 9, 71-87. doi:10.1163/156853001300109008

Flynn, C. P. (2002). Hunting and illegal violence against humans and other animals: Exploring the relationship. Society \& Animals: Journal of Human-Animal Studies, 10, 138-154.

doi:10.1163/156853002320292291

Frattaroli, S. (2009). Removing guns from domestic violence offenders: An analysis of state level policies to prevent future abuse. Baltimore, MD: The Johns Hopkins Center for Gun Policy and Research. Retrieved from http://www.jhsph.edu/bin/u/q /RemovingGunsfromIPVOffenders7Oct09.pdf

Gansler, D. F. (2008). First strike: The violence connection. Washington, DC: Humane Society of the United States. Retrieved from http://www.humanesociety.org/assets/pdfs/a buse/first_strike.pdf

Gordon, L. (2007). What do kids think about frogs? Retrieved from

http://www.izea.net/education/Attitudes $\% 20$ towards\%20frogs-Gordon.pdf

Gosling, S. D., Vazire, S., Srivastava, S., \& John, O. P. (2004). Should we trust webbased studies? A comparative analysis of six preconceptions about Internet questionnaires. American Psychologist, 59, 
93-104. doi:10.1037/0003-066X.59.2.93

Hanna, C. A. (2011). Reducing murders in the Bahamas: A strategic plan based on empirical research. Nassau, Bahamas: Royal Bahamas Police Force. Retrieved from

http://www.royalbahamaspolice.org/adobe/ Reducing_Murders_in_The_Bahamas.pdf

Henry, B. C., \& Sanders, C. E. (2007). Bullying and animal abuse: Is there a connection? Society \& Animals: Journal of Human-Animal Studies, 15, 107-126. doi:10.1163/156853007X187081

Howard, L., \& Vick, S. (2010). Does it bite? The role of stimuli characteristics on preschoolers' interactions with robots, insects and a dog. Anthrozoös: A Multidisciplinary Journal of the Interactions of People \& Animals, 23, 397-413. doi:10.2752/175303710X12750451259499

Hsieh, S. C. (2006). A corpus based study on animal expressions in Mandarin Chinese and German. Journal of Pragmatics, 38, 22062222. Retrieved from http://research.ncku.edu.tw/re/articles/e/200 80215/4.html.

Humane Society of the United States. (2004).

First strike ${ }^{\circledR}$ campaign 2003: Report of animal cruelty cases. Washington, DC:

Author. Retrieved from: http://www.humanesociety.org/assets/pdfs/2 003AnimalCrueltyRprt.pdf

Kaufman, S. R. (2010). Religion: A friend or foe to animals? [Review of the book Kinship and killing: The animal in world religion, by Wills Perlo, K.]. Society \& Animals: Journal of Human-Animal Studies, 19, 228-229. doi:10.1163/156853010X492060

Knowles, L. M. (2000). The impact of physical abuse on the psychological and behavioural state of institutionalised children in the Bahamas and Jamaica. (Unpublished doctoral dissertation).
University of the West Indies, Mona, Jamaica.

Lips, H. (2008). Sex and gender: An introduction (6th ed.). Boston, MA: McGraw-Hill.

Lockwood, R., \& Ascione, R. (Eds.). (1998). Cruelty to animals and interpersonal violence: Readings in research and application. West Lafayette, IN: Purdue University Press.

Maas, C., Herrenkohl, T. I., \& Sousa, C. (2008). Review of research on child maltreatment and violence in youth. Trauma, Violence \& Abuse, 9, 56-67. doi: $10.1177 / 1524838007311105$

Maundeni, T. (2000). Children living in violent families: Implications for social work in Botswana. Botswana Journal of African Studies, 14, 165-171. Retrieved from http://archive.lib.msu.edu/DMC/African $\% 20$ Journals/pdfs/PULA/pula014002/pula01400 2004.pdf

McEwen, F. (2010). Research review: Animal abuse, child abuse and domestic violence. Community Care Inform. Retrieved from http://www.ccinform.co.uk/Articles/2010/01 /12/4231/Animal+abuse, + child + abuse + and + domestic+violence.html

McPhredran, S. (2009). Animal abuse, family violence, and child wellbeing: A review. Journal of Family Violence, 24, 41-52. doi:10.1007/s 10896-008-9206-3

Mellor, D., Yeow, J., bt Mamat, N. H., \& bt Mohd Hapidzal, N. F. (2008). The relationship between childhood cruelty to animals and psychological adjustment: A Malaysian study. Anthrozoös: A Multidisciplinary Journal of the Interactions of People \& Animals, 21, 363-374. doi:10.2752/175303708X371582

Merz-Perez, L., \& Heide, K. M. (2003). Animal cruelty: Pathway to violence against 
people. Lanham, MD: Rowan \& Littlefield.

Nunez, P. (2010, September 13). The nature of the beast. The Tribune. Retrieved from http://www.tribune242.com/editorial/Insight /09132010_Insight_opinion-pg

Oleson, C. J., \& Henry, B. C. (2009).

Relations among need for power, affect and attitudes towards animal cruelty.

Anthrozoös: A Multidisciplinary Journal of the Interactions of People \& Animals, 22, 255-265. doi:10.2752/175303709X457595

Otterbein, C. S., \& Otterbein, K. F. (1973). Believers and beaters: A case study of supernatural beliefs and child rearing in the Bahama Islands. American Anthropologist, 75, 1670-1681. doi:10.1525/aa.1973.75.5.02a00290

Pagani, C., Robustelli, F., \& Ascione, F. R. (2007). Italian youths' attitudes towards and concern for animals. Anthrozoös: A Multidisciplinary Journal of the Interactions of People \& Animals, 20, 275-293. doi:10.2752/089279307X224818

Pagani, C., Robustelli, F., \& Ascione, F. R. (2010). Investigating animal abuse: Some theoretical and methodological issues. Anthrozoös: A Multidisciplinary Journal of the Interactions of People \& Animals, 22, 259-276. doi:10.2752/175303710X12750451259011

Patterson-Kane, E. G., \& Piper, H. (2009). Animal abuse as a sentinel for human violence: A critique. Journal of Social Issues, 65, 589-614. doi:10.1111/j.15404560.2009.01615.x

Petersen. M. L., \& Farrington, D. P. (2007). Cruelty to animals and violence to people. Victims and Offenders, 2, 21-43. doi:10.1080/15564880600934187

Plumridge, S. J., \& Fielding, W. J. (2009). Domestic violence in the homes of college students, New Providence, The Bahamas. The College of The Bahamas Research
Journal, 15, 45-55. Retrieved from http://journals.sfu.ca/cob/index.php/files/arti cle/view/116/122

Risley-Curtiss, C., Zilney, L.A., \& Hornung, R. (2010). Animal-human relationships in child protective services: Getting a baseline. Child Welfare, 89(4), 67-82.

Rivett, M., \& Kelly, S. (2006). From awareness to practice: Children, domestic violence and child welfare. Child Abuse Review, 15, 224-242. doi:10.1002/car.945

Rolle, U. (2009). [Interviews with Percy Grant, Bahamas Humane Society]. Unpublished raw data.

Rudy, K. (2008). The role of gender in our social treatment of nonhuman animals. Society \& Animals: Journal of HumanAnimal Studies, 16, 195-196. doi:10.1163/156853008X291480

Sawyer, A. (2002). [Bahamian perceptions, attitudes and beliefs on animal cruelty]. Unpublished raw data.

Sherin, K. M., Sinacore, J. M., Li, X., Zitter, R. E., \& Shakil, A. (1998). HITS: A short domestic violence screening tool for use in a family practice setting. Family Medicine, 30(7), 508-12. Retrieved from http://www.stfm.org/fmhub/FULLPDF/JUL YAUG98/cram1.pdf

Sliwinski, T. (2007). Domestic violence: Weapons issues. Retrieved from http://www.divorcenet.com/states/new_jerse y/domestic_violence_weapons

Stibbe, A. (2001). Language, power and the social construction of animals. Society \& Animals: Journal of Human-Animal Studies, 9, 145-161. doi:10.1163/156853001753639251

Swan, D., \& McCarthy, J. (2003). Contesting animal rights on the Internet: Discourse analysis of the social construction of argument. Journal of Language and Social Psychology, 22(3), 297-320. 
doi:10.1177/0261927X03252279

Tallichet, S. E., \& Hensley, C. (2004).

Exploring the link between recurrent acts of childhood and adolescent animal cruelty and subsequent violent crime. Criminal Justice Review, 9, 302-316. doi:10.1177/073401680402900203

Tallichet, S. E., Hensley, C., \& Singer, S. D. (2005). Unraveling the methods of childhood and adolescent cruelty to nonhuman animals. Society \& Animals: Journal of Human-Animal Studies, 13, 91107. doi: $10.1163 / 1568530054300172$

Taylor A. M., Reby, D., \& McComb, K. (2010). Why do large dogs sound more aggressive to human listeners: Acoustic bases of motivational misattributions. Ethology, 116,1155-1162. doi:10.1111/j.1439-0310.2010.01829.x

Taylor, N., \& Signal, T. (2009). Lock 'em up and throw away the key? Community opinions regarding current animal abuse penalties. Australian Animal Protection Law Journal, 3, 33-52. Retrieved from http://www.animalsandsociety.org/assets/31 8_taylorsignallawjournal09.pdf
Thompson, K. L., \& Gullone, E. (2008).

Prosocial and antisocial behaviors in adolescents: An investigation into associations with attachment and empathy. Anthrozoös: A Multidisciplinary Journal of the Interactions of People \& Animals, 21, 123-137. doi:10.2752/175303708X305774

United Nations Statistics Division. (2009). Internet users per 100 population: Bahamas. Retrieved from http://data.un.org/Data.aspx?q=Internet+use rs+BAHAMAS\&d=MDG\&f=seriesRowID $\% 3$ a605\%3bcountryID\%3a44

Wright, J., \& Hensley, C. (2003). From animal cruelty to serial murder: Applying the graduation hypothesis. International Journal of Offender Therapy and Comparative Criminology, 47, 71-88. doi:10.1177/0306624X02239276

Yamazaki, S. (2010). A comparison of maltreated children and non-maltreated children on their experiences with animals: A Japanese study. Anthrozoös: A Multidisciplinary Journal of the Interactions of People \& Animals, 23, 55-67. doi:10.2752/175303710X1267079939189 